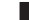

\section{CHALLENGES IN DEVELOPING AND SUPPORTING ENTREPRENEURSHIP EDUCATION: A CASE STUDY OF THE UNIVERSITY OF ZULULAND}

\author{
Thobile N Radebe Masters Candidate ${ }^{1}$ Orcid ID: 0000-0002-9571-1408, \\ Dr Makhosazana F Vezi-Magigaba² Orcid ID: 0000-0003-0614-7751
}

\begin{abstract}
:
Entrepreneurship education is broadly considered an important factor in promoting an entrepreneurial culture among higher education students. Considering the importance of entrepreneurship with regard to economic growth, job creation and poverty alleviation, there is a need to train entrepreneurs and to equip them with an entrepreneurial culture that promotes entrepreneurship. However, the South African education system is lacking when it comes to entrepreneurship education. The education system seems to promote the white-collar jobs rather than self-employment, and the methodology that is used to teach entrepreneurship studies, focuses more on the theory of entrepreneurship than on its practice. Against this background, this study sought to identify the challenges to develop and support entrepreneurship education by focusing on the University of Zululand as a case study. The researcher used primary data for this study. The study adopted a qualitative approach, where data was collected using interview schedules from 11 heads of departments of the university's faculties. The results from the study show that the development of curriculum, inexperienced educators, and the methodology used to teach entrepreneurship education, are some of the challenges that are hindering the promotion of entrepreneurship education. A policy implication that arose from these findings, is that there is a need for the development of entrepreneurship-based curriculum to promote entrepreneurship. The policymakers were also encouraged to employ educators who are qualified and experienced in teaching entrepreneurship. The development of incubation centres for grooming entrepreneurs at higher learning institutions was also recommended.
\end{abstract}

Keywords: Entrepreneurship education, entrepreneurship education challenges, entrepreneurship culture

\section{Introduction}

The importance of entrepreneurship education has been recognised by many studies. The study by Chimucheka (2013) is such an example, since he pointed out that quality education and training plays an important role in the survival of SMEs in South Africa, and the more they are equipped with entrepreneurial competences, the more they survive and succeed. An educated workforce that is properly skilled and that has the capacity for innovation, is very important for an economy's attractiveness, productivity and growth (Green \& Mason, 2014). A good education

\footnotetext{
'Department of Business Management, University of Zululand,

Private Bag X1001, KwaDlangezwa, 3886. Tel: 035902 6939,

Email: radebethobileh@gmail.com

${ }^{2}$ Department of Business Management, University of Zululand,

Private Bag X1001, KwaDlangezwa, 3886. Tel: 035902 612,

Email: MagigabaM@unizulu.ac.za
} 
structure is therefore one of the fundamental necessities for a competitive country, as it is equitable to trust that a good quality education structure will have an encouraging effect on individuals' self-efficacy and self-confidence. This will increase the chances of such individuals not only to formulate a business, but also to be able to successfully direct competitive and changing business environments (Department of Higher Education, 2017). GEM research (2016/2017) shows that there is a solid association between perceived capabilities (skills) and Total early-stage Entrepreneurial Activity (TEA), which strengthens that all systems of education (formal, informal and non-formal) are significant in developing entrepreneurial competences. Despite the important role of entrepreneurship education in promoting entrepreneurship in South Africa, there are numerous obstacles and problems that hinder the development of effective entrepreneurship education programmes (Lekoko, 2011 \& Echezona, 2015). Therefore, this study sought to identify the challenges that hinder the development of an effective entrepreneurship education in learning institutions.

Much empirical evidence exists on entrepreneurship and the importance of entrepreneurship and entrepreneurship education, however, little has been written about the challenges that are actually hindering the development of entrepreneurship education. The study seeks to fill that gap by evaluating what the factors are that affect the development of entrepreneurship education. The study will be conducted within the context of the University of Zululand, which makes it more interesting. Firstly, it is a remote rural university; secondly, the university is trying to be involved in entrepreneurship to expose students to entrepreneurship; thirdly, it is purely contextual, as it fills the void of limited literature that has been conducted in the context of KZN.

Section 1 of the paper covers an entrepreneurship education overview and the overview of the challenges hindering the development of entrepreneurship education. The objective is to review the entrepreneurship education system and to illustrate how it is designed and delivered, and also to identify what challenges are in place that prevent the development of entrepreneurship. Section 2 looks at the empirical literature to review other authors' work on the topic. Section 3 covers the theoretical framework of the study, which is followed by Section 4 that covers the methodology. Concluding remarks are given in Section 5.

\section{An overview of entrepreneurship education}

Quality entrepreneurship education plays an important role in improving the culture of entrepreneurship in students or learners, since they then grow up with the mindset of creating their own businesses as the entrepreneurship foundation is then instilled in them from a young age (Echezona, 2015). Mahola, Aderibigbe \& Chimucheka (2019) stated that entrepreneurship education is very important in developing skills and knowledge that enable entrepreneurs to harness opportunities. Furthermore, entrepreneurship education plays a leading role for entrepreneurs in improving market awareness, creativity and innovation, the ability to gather resources, and business and technical skills. Moreover, it has also been promoted in many educational institutions, because of the role it played in nurturing entrepreneurs. It is also recommended as a solution to the challenges faced by South Africa (Mahola et.al, 2019).

According to Ememe (2011), entrepreneurship education plays an important role in enabling the youth to seek for success in ventures, and it also builds entrepreneurial mindsets of students. Entrepreneurship education provides students with the awareness of economic opportunities, the business environment, opportunity identification, and preparation of business plans, enterprise management techniques, self-development techniques, as well as general entrepreneurial skills (Akhmetshin, Larionova, Lukiyanchina, Savitskaya, Aleshko, and Aleynikova, 2019). In addition, Suleiman (2010) added that entrepreneurship education equips people, particularly the youth, with skills and knowledge which transform them into enterprising individuals by engaging them in real-life learning experiences in which they can take risks, manage results, and learn from the outcomes.

Improved entrepreneurial education could make an important contribution to job creation, poverty alleviation, and also to economic development (Isaacs et al.2007 \& Chimucheka, 2013). Niema and Nieuwenhuizen (2009) further pointed out that higher level of education and training is considerably associated with higher level of entrepreneurial activity. Fatoki and Odeyemi (2010) stated that for SMEs to get the required funding from creditors, they often have to prove that they have the relevant education and related experience, which improve their managerial competency. Therefore, in their view, entrepreneurship education positively affects funding opportunities.

Entrepreneurship education equips learners with entrepreneurial skills that are needed to start and sustain the business, and it also helps to expose students to the real business world, which gives them the ability to overcome 
challenges that they might face in running a business (Department of Higher Education, 2017). Modules, courses and degrees at universities and learning institutions can have a positive impact on a student's entrepreneurial abilities, since they can equip and prepare students with the entrepreneurial skills and knowledge that are needed to boost their entrepreneurial attitudes to start and sustain their businesses (Udu \& Amadi, 2013).

\section{Challenges that are hindering the development of effective entrepreneurship education in South Africa}

Entrepreneurship education has been recognised as the most important tool in promoting entrepreneurship activities for every country. However, it is very unfortunate that there are challenges in place that hinder the development of entrepreneurship education. One of the major challenges in promoting entrepreneurship is, that most higher education institutions lack quality teachers or instructors who are knowledgeable in the field of entrepreneurship (Echezona, 2015). Molefi (2015) complained that most lecturers did not have personal exposure to entrepreneurship, as they did not own or operate businesses. Entrepreneurship education does not only entail teaching people how to run a business, but it also involves training an individual to think creatively and to promote a strong sense of self-worth and accountability (Ebele, 2008 and Cui, Sun, and Bell, 2019). Echezona (2015) in Obiefuna et al. (2010), added that the educators dwelt mostly on theories, leaving out the practical aspect of learning by demonstration, which led to inadequate and ineffective learning. In addition, these researchers demanded that entrepreneurship learners should be exposed to the three domains of learning, namely cognitive, affective, and psychomotor.

Ebewo \& Shambare (2012) stated that the syllabus is not broad enough to prepare individual students to acquire practical entrepreneurial skills, knowledge and experience. The syllabus that learning institutions provide to students, does not change the students' mindset to become entrepreneurs. It rather encourages students to become jobseekers which is not the solution that the country needs. The challenge is that the syllabus is inappropriate to give students the proper foundation for entrepreneurship and to build an entrepreneurship culture in students (Varblane \& Mets, 2010). Echezona (2015) stated that South African learning institutions are lacking useful course content that is in line with the economic realities of the country. Strydom \& Adams (2009) stated that the teaching methods that allow for practical application of learning material, as well as holistic development of skill sets, are lacking at these learning institutions. In the EDHE Lekgotla conference of 2018, it was pointed out that the methodology that is used does not empower students to develop free, innovative and creative thinking in the application of knowledge and theory in the real world.

Many students are lacking exposure in the field of entrepreneurship and the realities within the South African context, and this can be explained in two different ways. Firstly, because of high poverty rates, students who come from very poor backgrounds are usually not exposed to the wider world out there (Echezona, 2015). Entrepreneurship demands a talented workforce, but the present system of education fails to provide the necessary foundation for such a workforce. The schools up to the tertiary level, currently do not have a well-developed curricular that gives students the required entrepreneurial skill, and they do not expose their students or learners to the real business world (Chimucheka, 2012).

The necessary drive for an entrepreneur is lacking, and this leads to poor performance in entrepreneurship (Echezona, 2015). As a result of the apartheid legacy, the entrepreneurial intentions of black students fall below fifty percent, compared to those of other races (Global Entrepreneurship Monitor, 2011). Similarly, the Bantu Education system during the apartheid regime, results in the ill-prepared students at universities. Most universities are underfunded and under-resourced, which means that several universities cannot afford to provide the proper training to increase the students' exposure.

The pressure from parents who believe that after graduation their children have to go and seek for jobs to make money is a challenge (Echezona, 2015). This makes it difficult for young people to dedicate enough time that is required for entrepreneurship training, as they have to make money in the short period of time (Varblane \& Mets, 2010 \& Nani, 2016). Osakwe (2011) and Echezona (2015) stated that the society's poor attitude towards entrepreneurship education and training, is a big challenge for the youth who want to start their own businesses. The author stated that society believes that education which exposes people to white-collar jobs, is superior to education that leads to the attainment of entrepreneurship skills.

In this respect, Bukola (2011) expresses disappointment regarding society's attitude towards entrepreneurship training, and thus stated that graduates of vocational and technical institutions anywhere in the world are extremely 
skilled entrepreneurs, but society does not seem to encourage the youth to follow suit. Additionally, it is unfortunate that those who influence education policy in the society (legislators, educators and the media, among others), seem to feel that graduates of technical institutions are not equal to university graduates (Bukola, 2011). Thus, this has affected the insights of even the students of vocational and technical institutions that hold some entrepreneurship background, but who lacked entrepreneurial essence even before graduation.

\section{Problem statement}

The unemployment rate in South Africa is exceptionally high and the failure rate of entrepreneurship is very high too. Many scholars identified the solution to be the development of an effective entrepreneurship education, where students are groomed to be better entrepreneurs. However, it has been identified that the South African entrepreneurship education system is failing to provide the necessary skills and knowledge needed to instil entrepreneurship mindsets and culture for the potential entrepreneurs. Therefore, this paper aims to identify the challenges that hinder the development of an effective entrepreneurship education.

\section{Methodology}

The study used a qualitative research approach in meeting the objectives. The study's sample was drawn from the University of Zululand heads of departments of the selected faculties. The sample size was 11 heads of departments (HoDs). Seven HoDs were selected from the departments that do not teach entrepreneurship, and 4 were selected from departments that do teach entrepreneurship. These HoDs were randomly selected. Interview schedules were used to collect data from the HoDs and this was analysed using Atlas.ti 8.

\section{Theoretical Framework}

\section{The need for achievement theory (NAT)}

The need for achievement theory is a psychological theory proposed by David McClelland in 1965. The theory is based on the psychological and biological views that human needs and actions are a response to internal and external stimuli. The theory further distinguished between natural needs like food and water, and acquired needs. External stimuli in the environment can create an acquired need, just as much as it creates a natural need (Chen et al. 2012). Human beings generally exhibit three types of acquired needs - the need for achievement, the need for power and the need for association (Rashipal, 2012; Chen at al. 2012).

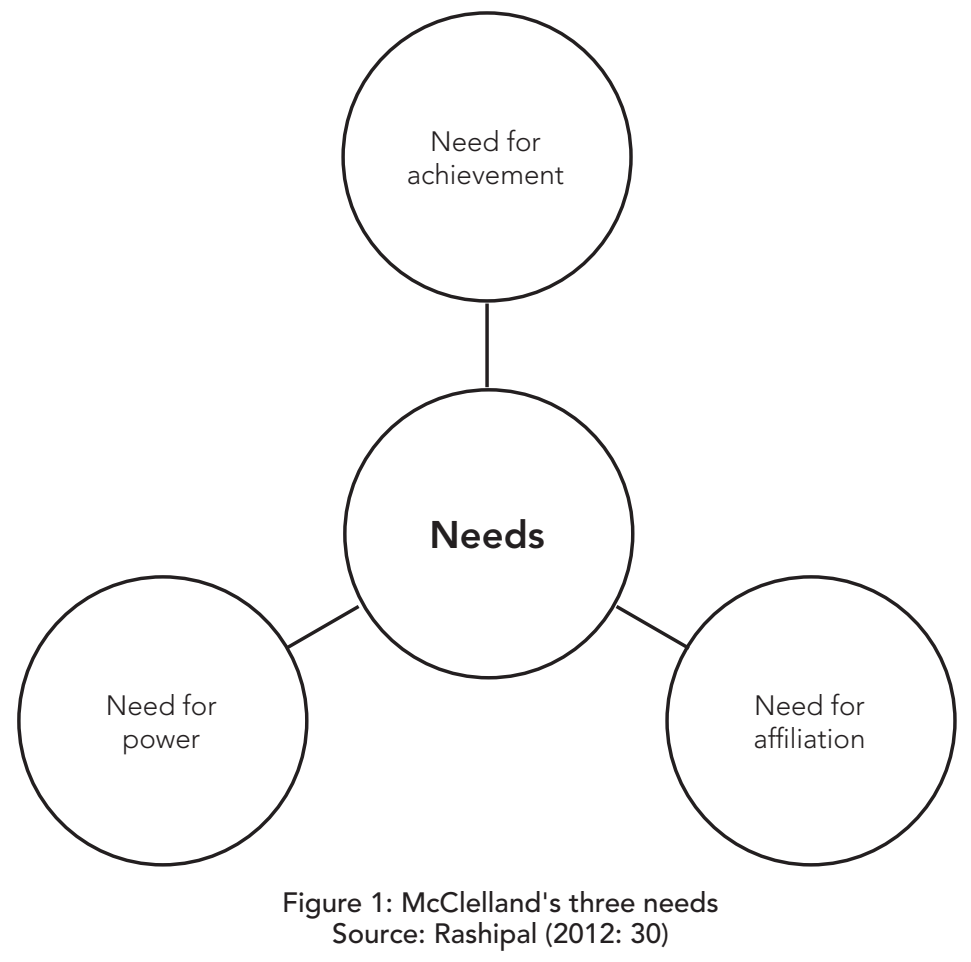

Entrepreneurial success which includes establishing a successful business, gainfully benefiting from the business, providing employment and achieving personal wealth, all mostly fall under the need for achievement (Rashipal, 2012). This need is centred on the development of personal goals and working towards their attainment. 
The theory points out a strong association between the need for achieving economic development and entrepreneurial activities (Rashipal \& Jain 2012 \& Echezona, 2015). Echezona (2015) further stated that supporters of the theory explain that there would be more entrepreneurial activities in a society where the need for entrepreneurship is high. The root of the theory is that when students or learners are adequately motivated through entrepreneurship education to become entrepreneurs, there is a greater tendency for them to start their own businesses after graduation (Echezona, 2015). Teaching students about the importance of entrepreneurship and motivating them to become their own bosses rather than becoming employees, can help in creating more businesses, and that will also reduce the high unemployment rate, especially among the youth. The role of entrepreneurship education is therefore to instil a need and a motivation for students to learn entrepreneurship and to start a business.

This theory is relevant to this study because it emphasises that needs are developed through education, exposure and experience. Individuals who have not been exposed to the benefits of entrepreneurship, for example, will not develop a need to start a business. Theoretically, higher education institutions develop needs in students mainly through their curricula. Thus, an educational system or institution that emphasises job attainment rather than job creation, will mostly create graduates who prefer to be jobseekers than job creators. Similarly, educational institutions that put emphasis on practical entrepreneurship, are most likely to develop an entrepreneurial mindset that develops future entrepreneurs.

\section{Results and Discussions}

The 11 respondents expressed various views on challenges that affected the successful delivery of entrepreneurship education and entrepreneurship development at the university. These challenges were: mindset challenges; Lack of incubators and start-up facilities; Lack of adequate financial support; and Workload and capacity challenges.

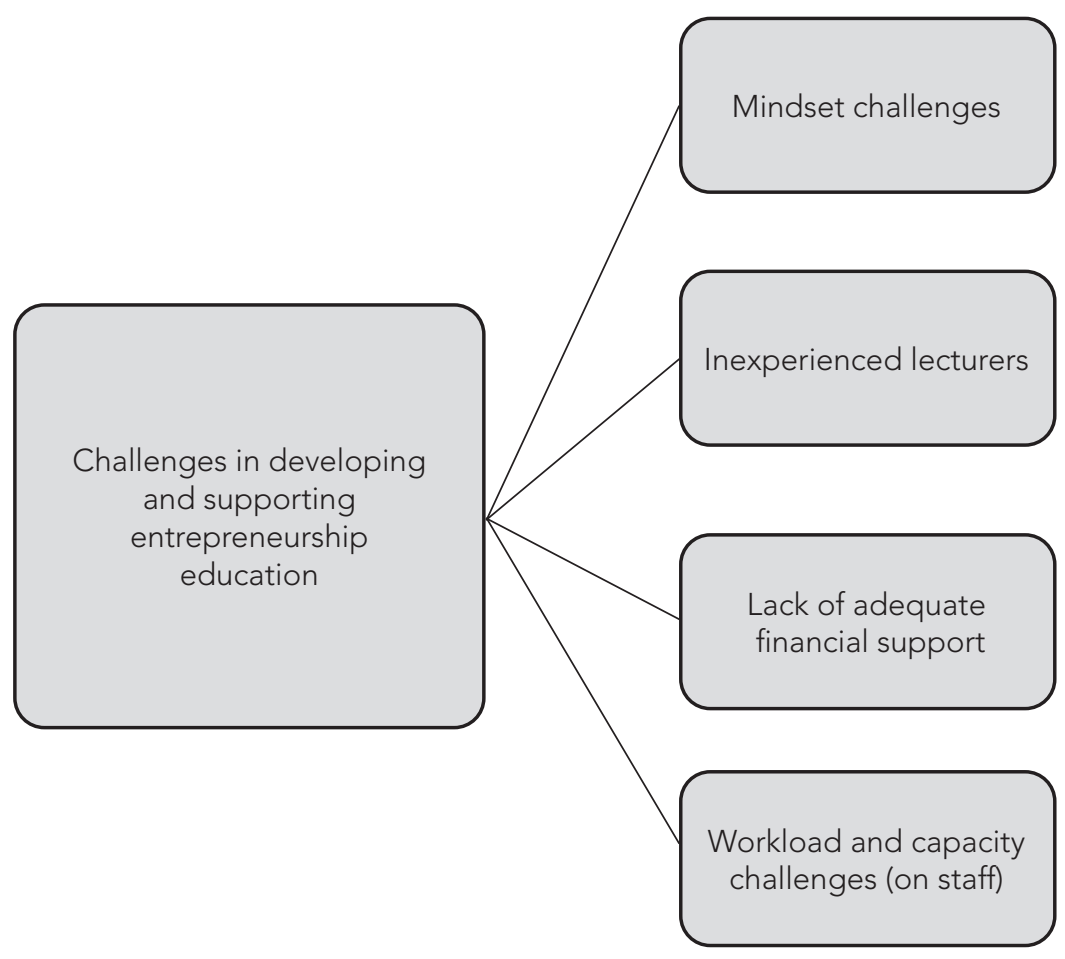

Figure 2: Challenges in Developing and Supporting Entrepreneurship Education Source: own compilation, 2019

As shown above, three of the challenges related to financial, material and human capital resources. One challenge related to mentality issues, and this theme, based on the responses of the respondents, was of major significance in explaining the current state of promotion of entrepreneurship, both in the country and at the university. Research Question 1, relates challenges to any factors that limit the university's capacities to fully promote entrepreneurship through teaching. Research Question 2, relates challenges to factors that perpetuate the failure of learning to equip young people with entrepreneurship skills. 
Respondent 11 saw the traditional mindset of students as a challenge. According to the respondent, students do not believe that they could succeed in entrepreneurship: "The first challenge is about the mindset, our students think that they are not capable of owning their businesses and the management or leader's mindset is not entrepreneurial... The challenge is how we going to change the mindsets of students where our mindsets still need to be changed". The same respondent saw the challenge as starting from the basic education level that does not prepare students for entrepreneurship. Respondent 5 saw the mindset challenge as a result of a lack of innovation and flexibility in HEl leadership in entrepreneurship development. The leaders still promoted traditional teaching and mindsets that did not put entrepreneurship at the forefront. Respondent 5: "It is the thinking of the leadership of higher education, they prescribe what universities must do and at what level, they are not flexible in terms of their thinking and they are not thinking outside the box, they only limit themselves with the book." Respondent 9 also believes in the need to change the mindset not only of the students, but also of the university leaders. The respondent further stated: "The leaders' mindset is to train the jobseekers not job creators". Likewise, Respondent 3 views the mindset issues as emanating from HEls and the academics themselves and cascading to their students. Respondent 2's views of mindset challenges were generational and they were a function of pats societies not seeing the benefits of being an entrepreneur.

Under the mindset challenge, the main discussion was that the promotion of entrepreneurship culture among students was being hindered by strong and existing mentalities, particularly the mentality that job seeking was more important than job creating. Students were raised and groomed with the expectation that once they left an educational institution, their success will be measured by getting a job rather than creating a business. The participants identified society (family and communities), the educational system, and educational leadership as the key drivers of this mentality. The existing education system is encouraging more jobseekers and less job creators (Varblane and Mets, 2010, Chimucheka, 2012, Echezona, 2015 and Mohola et.al, 2019). The authors further mentioned that the existing society and the system also contribute towards the belief that white-collar jobs are superior to self-employment.

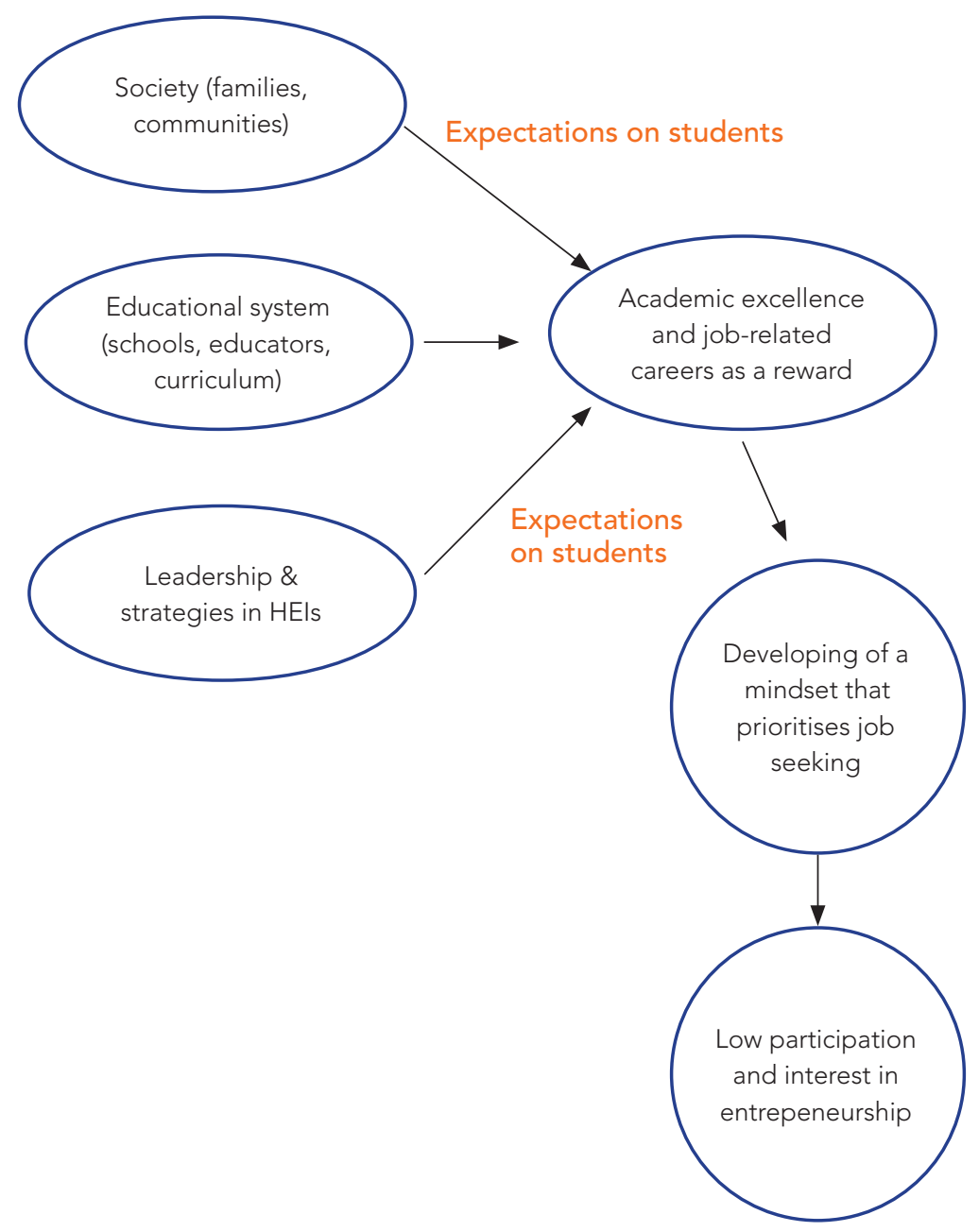

Figure 3: Society and the Entrepreneurship Mindset in Students Source: Own compilation, 2019 
According to the views of the participants, students as portrayed in the above diagram, merely respond to the broader expectations that they should be educated to get good jobs. The overall effect was a low participation in entrepreneurship by younger people.

According to the literature, several scholars (Echezona, 2015; Arasti, et al. 2012; Udu \& Amadi, 2013 \& Venter et al. 2015) discussed similar effects of the current student mindset on entrepreneurship as shaped by society. Arasti et al. (2012) and Venter et al. (2015) put entrepreneurship education at the centre of how to positively change a student's mindset towards becoming an entrepreneur. Therefore, entrepreneurship education has to counter the negative mentalities of becoming entrepreneurs that are instilled in young people. At organisational level, the Junior Achievement South Africa (JASA, 2012) indicates that changing one's mindset towards entrepreneurship is a critical building block in grooming future entrepreneurs, and therefore this is one of its priorities (JASA, 2012).

The participants' views strongly agree with Uzoagulu (2012), who stated that while the mindset challenges issue was a well-known fact, universities current form of entrepreneurship education was not strong enough to fully dismantle these issues. This is because entrepreneurship education is not given priority, which further perpetuates the mentality that entrepreneurship is not as important as career development through getting a job. Udu and Amadi (2013), as discussed in the sample, saw communities and families as important factors in entrepreneurship mindset development. Because parents tend to look down on entrepreneurship, they develop a view that being an entrepreneur was less important and less prestigious than being an employee - a mindset that discouraged the development of an entrepreneurship culture in students.

Another challenge that was highlighted by the respondents is related to a lack of financial support. The findings indicate that the university do not have any comprehensive financial support for entrepreneurship projects. The respondents, however, believe that this problem would come to an end once an entrepreneurship centre is created and implemented. The findings reveal that because of limited financial resources, it is not possible to conduct wider practical studies in entrepreneurship. Respondents also believe that financial support was possible if the university established a vision that can be accepted by government. Respondent 11's viewpoint is that as much as finance is a challenge, the university also lacks the vision and plan that could attract funding.

Various sources in the literature (Chimicheka, 2012 and Echezona, 2015) stated that financial resource challenges were discussed as a major hindrance in the promotion of entrepreneurship at the university. Without financial resources, it was also a challenge to build infrastructure and facilities necessary to support entrepreneurship (Agnonlahor, 2016 \& GEM, 2016).

While many scholars like Chimucheka (2012), Boates (2013) and Herrington et al. (2014) mention access to capital as a major problem affecting the promotion of entrepreneurship, the participants did not view this as the main factor hindering the promotion of a strong entrepreneurship culture among the youth. The challenge at university level was mostly access to facilities that supported entrepreneurial development, rather than funding. The sample did not explicitly state that obtaining funding was easy. However, it suggested that there were more primary concerns that needed to be addressed before the funding stages, e.g. mindset issues, proper vision, and the university's own activities and resources.

The findings revealed that a common challenge that educators at the university faced with regard to promoting entrepreneurship, was that it involved a lot of work, for which they did not have enough time: "Workload, lot of meetings, and lot of lecturing. I wish I could take students to the process of entrepreneurship but time is limited" (Respondent 8). In addition to their conventional teaching role, they needed to guide students individually through entrepreneurship processes and this takes a lot of time. The current workforce of academics was already burdened with teaching, which prevented them from taking on more demanding entrepreneurship education courses. Entrepreneurship education as stated, requires a significant practical component where the educator needs to fully participate. However, this was not possible, given that the same educators taught regular courses, and therefore they did not always have enough time on their hands to take on or develop more efficient entrepreneurship education regimes. The above view of the respondents was not discussed in other works consulted by the researcher, and this points to a possible unique or new factor that could also explain the poor promotion of entrepreneurship at universities.

Another work-related factor that resulted from the findings, was that of practical experience and competence of lecturers in delivering entrepreneurship education. The participants indicated that most lecturers did not train for entrepreneurship teaching and had no practical experience of it. This tends to reduce their effectiveness in 
delivering information and support that transform students into entrepreneurs and support their entrepreneurship ventures. In the literature, Uzoagulu (2012), Zhou and Haixia (2012), and Agbonlahor (2016) also found that lecturers who taught entrepreneurship did not have a strong practical grasp of the discipline, due to training issues. Uzoagulu further associates this problem with low prioritisation of entrepreneurship education at universities. With entrepreneurship education that is ranked lowly, not many resources was available to promote educator education. The observations and perceptions of the study on this matter therefore strongly resonate with the literature.

\section{Conclusions and Recommendations}

The study found that there is a need to employ educators who are qualified and experienced in teaching entrepreneurship and to develop it as an activity for students. The study further revealed that academics were sometimes expected to educate students on entrepreneurship, but they were not always knowledgeable regarding this discipline. This was stated to be the case with educators outside commercial and economic disciplines. This highlighted that even the entrepreneurship educators have no entrepreneurial experience and that they are not entrepreneurial-minded.

The collaboration across departments was identified as another way of promoting entrepreneurship. Currently, fewer departments and professionals are involved and this makes current entrepreneurship efforts less effective in the development of students as entrepreneurs.

The findings reveal that entrepreneurship should be encouraged and promoted through teaching society about its value, and particularly the families that students come from. It is in these families that students got the mindset that it was better to get a job than to become an entrepreneur.

The findings reveal that the jobseeker mentality was a national and generational issue, rather than a university issue. The respondents believe that mindset change should focus not only on students, but on the whole academic system from students to the university leadership. The findings reveal that the mindset issue also involves changing the view that to start a successful business one needs to have a lot of money. Students were being deterred from starting out as entrepreneurs because of this view.

Early engagement of students in entrepreneurship education was identified as the best way of promoting entrepreneurship education among students. Engaging students at an early stage in entrepreneurship education, will lay a solid foundation for students to grow up with entrepreneurship mindsets.

The findings reveal that the university has no practical facilities that are developed to promote entrepreneurship and entrepreneurship module that is designed for a particular group of students. The study recommends that there should be a development of practical facilities and an entrepreneurship module, so that all students will be exposed to entrepreneurship education as well as how the real business world operates.

\section{References}

Agbonlahor, A. A. (2016). Challenges of entrepreneurial education in Nigerian Universities: Towards a repositioning for impact. Journal of educational and social research, 6(1), 208.

Akhmetshin, E.M., Larionova, G.N., Lukiyanchina, E.V., Savitskaya, Y.P., Aleshko, R.A. and Aleynikova, O.S., 2019. The influence of educational environment on the development of entrepreneurial skills and competencies in students. Journal of Entrepreneurship Education, 22, pp.1-13.

Arasti, Z., Falavarjani, M. K., \& Imanipour, N. (2012). A Study of Teaching Methods in Entrepreneurship Education for Graduate Students. Higher education studies, 2(1), 2-10.

Boates, C. (2013). Too Many Obstacles Still Hindering SA's Entrepreneurial Growth: The EOY team posted on June 4, 2013

Bukola, A. B. (2011). Entrepreneurship Foundation: An Imperative for Sustainable Development in Nigeria: Journal of Emerging Trends in Educational Research and Policy Studies, 2(1), 26-29

Chen, S., Xuemei S., \& Sibin W. (2012). "Need for Achievement, Education and Entrepreneurial Risk Taking Behavior." Scientific Journal Publisher, Social Behavior and Personality: An international Journal 40(8), 1311-1318.

Chimucheka, T. (2012). The impact of entrepreneurship education on the performance of Small, Micro and Medium Enterprises in the Buffalo City Metropolitan Municipality. Published (masters.), University of Fort Hare. 
Chimucheka, T. (2013). Overview and performance of the SMMEs sector in South Africa. Mediterranean Journal of Social Sciences, 4(14), 783-783.

Cui, J., Sun, J. and Bell, R., 2019. The impact of entrepreneurship education on the entrepreneurial mindset of college students in China: The mediating role of inspiration and the role of educational attributes. The International Journal of Management Education, p.100296.

Department of Higher Education. (2017). "Findings on Entrepreneurship in the SA University System, and the Broader Context of Entrepreneurship in the South African Public Education System." <https://edhe.co.za/wpcontent/uploads/Dr_T_Blecher-Findings_on_entrepreneurship_in_the_SA_University_System.pdf>.

Ebele, O.P. (2008). Introduction of entrepreneurship education in business education curriculum at university level in Nigeria. International Journal of Ghana, 3 (1), 30.

Ebewo, P. E., \& Shambare, R. (2012, May). The reason business plans of start-up ventures are rejected by South African financiers: Evidence from SIFE-TUT Harmony Fashion Design Business Challenge. In Emerging Markets Conference of the International Management Research Academy (IMRA). London (pp. 17-18).

Echezona, M. (2015). Entrepreneurship education as a strategy for the promotion of entrepreneurship culture and poverty reduction among university students. Published (Masters.), University of Fort Hare.

EDHE Lekgotla conference (2018). Enhancing entrepreneurship education among Universities. Cape Town.

Ememe, O.N. (2011). Entrepreneurship education in the University in the Eastern Nigeria; implications for higher education administration. Unpublished PhD dissertation, University of Port-Harcourt.

Fatoki, O. \& Odeyemi, A. (2010). Which new small and medium enterprises in South Africa have access to bank credit? International Journal of Business and Management, 5(10), 128.

Global Entrepreneurship Monitor global Report. (2011). Global Entrepreneurship Research Association, London Business School.

Global Entrepreneurship Monitor Report. (2016). Accountability in education: meeting our commitments. Retrieved from: https://www.gemconsortium.org/report/49812.

Global Entrepreneurship Monitor. (2016/2017). Can small businesses survive in South Africa?

Green, F \& Geoff M. (2014). Skills and training for a more innovation-intensive economy. Discussion Paper No. 431. Oxford: National Institute of Economic and Social Research.

Herrington, M., Kew, P. \& Kew, J. (2014). GEM South Africa 2013 Report [Online] retrieved from: http:// www. gemconsortium.org/docs/3336/gem-south-africa-2013-report.

Isaacs, E., Visser, K., Friedrich, C. \& Brijlal, P. (2007). Entrepreneurship education and training at the Further Education and Training (FET) level in South Africa. South African Journal of Education, 27(4), 613-630.

Junior Achievement South Africa (2012). Retrieved from: http://www. givengain.com.

Lekoko, M. (2011). Students' perceptions regarding entrepreneurship education: a case of two universities in Botswana.

Mahola, S., Aderibigbe, J.K. and Chimucheka, T., 2019. South African University Students' Entrepreneurial Intention as a Correlate of Entrepreneurship Risk Perceptions and Aversion. J Hum Ecol, 67(1-3), pp.1-8.

Molefi, M. (2015). Callsforentrepreneurship education in universities. Retrievedfrom:http://www.universityworldnews. com/article.php?story $=2015032413133496$

Nani, G.V. (2016). "Entrepreneurial education in the school curriculum: in search of positioning in Zimbabwe". "Problems and Perspectives in Management", 14(3), 85-90.

Nieman, G. \& Nieuwenhuizen, C. (2009). Entrepreneurship: A South African Perspective. Van Schaik.

Osakwe, R.N. (2011). A Survey on the perception of need for entrepreneurial skills acquisition among undergraduate students in Delta State University. Journal of Educational Research and Development, 10(1), 127-141.

Osuala, E.C. (2010). Principles and Methods of Business and Computer Education; Enugu: Cheston Agency Ltd Pub.

Rashipal, N.J. (2012). Need for achievement an antecedent for risk adaptiveness among entrepreneurs. Global Journal of Management and Business Research, 12(22). 
Strydom, R. \& Adams, M. (2009). Evaluating the learning experience of undergraduate entrepreneurship students exposed to unconventional teaching approach: a South African case study: Southern African Journal of Entrepreneurship and Small Business Management, 2(1), 50-67

Suleiman, H. (2010). Youth entrepreneurship education for national development. International Journal of Education Studies, 1(1), 47-50.

Udu, C.S. \& Amadi, U.P. (2013). Integrating basic entrepreneurship studies into primary education curriculum: Platform for sustainable national development. Academic Journal of Interdisciplinary Studies, 2(5), 69.

Uzoagulu, A.E. (2012). Entrepreneurial education in Nigeria. A keynote address presented at the 27th Annual congress of the Nigerian Academy of Education. November 5-9th, Minna, Niger State.

Varblane, U. \& Mets, T. (2010). Entrepreneurship education in the higher education institutions (HEIs) of postcommunist European countries. Journal of Enterprising Communities: People and Places in the Global Economy, 4(3), 204-219.

Venter, R., Urban, B., Beder, L., Oosthuizen, C., Reddy, C. \& Venter, E. (2015). Entrepreneurship: theory in practice. Oxford University Press Southern Africa.

Zhou, M. \& Xu, H. (2012). A review of entrepreneurship education for college students in China. Administrative Sciences, 2(1), 82-98. 